\title{
To the Posthuman Born(e): The Post-natural World of Jeff VanderMeer
}

Pramod K Nayar ${ }^{1}$

\section{Introduction}

One of the first things that strikes us about Jeff VanderMeer's newest addition to the expanding canon of the 'New Weird', Borme (2017) is the army of extraordinary creatures he imagines. First there is Mord, a bear as large as houses ('three stories'), and who can fly. Then there are 'Mord proxies':

[A]ll golden bears, all huge in their hideous beauty, much taller than a man, with thick muscles that, in their stride and bounding, came at times to the surface of their fur like the hardness of a vine-wreathed tree trunk wrung and stretched taut. ${ }^{2}$

Then there are feral children: "Some had iridescent carapaces. Some had gossamer wings. Some had fangs like cleavers that half destroyed their mouths. Soft and exposed and pink or hardened and helmeted, they spilled out." In addition, there are the 'diagnostic worms' and 'diagnostic beetles' that live inside Wick's skin (the other principal human protagonist of the novel): the beetles can run over the human form and detect injuries. But there are also other uses to these beetles:

The beetles Wick altered, or made from materials he'd stolen from the Company, didn't just teach when shoved in your ear; they could also rid you of memories and add memories. People who couldn't face the present shoved them into their ears so they could experience someone else's happier memories from long ago, from places that didn't exist anymore.

VanderMeer's novel about a post-apocalyptic age on earth teems with such bizarre life forms. In this essay, I argue that VanderMeer's imagining of such a world is at once posthuman and post-natural, and the two are interconnected. Indeed, the crux of the argument is that the posthuman is contingent upon, even as it produces, the post-natural.

\section{The post-natural}

The post-natural emerges in the context of the Company's workings over a period of time (although there is no time frame given in the novel). The Company has transformed the city

${ }^{1}$ Pramod K Nayar, Department of English, University of Hyderabad, India. Email: pramodknayar@gmail.com.

2 Unless otherwise stated, all quotations are from VanderMeer's novel, Borne. 
and its environs into a vast toxic landscape, so that there is no 'nature' anymore. Note the account of the land:

[The] writhings of the poisonous river that ringed most of the city. A stew of heavy metals and oil and waste that generated a toxic mist, reminding us that we would likely die from cancer or worse. Beyond the river lay a wasteland of scrub.

There are toxic oil pools everywhere, the land lies barren. ${ }^{3}$ Rosi Braidotti defines the postnatural as:

The 'post-natural' here is defined as the organisms that have been heritably altered by means including selective breeding or genetic engineering. Displays have included glowing fish with genes from bioluminescent jellyfish and coral, 'Biosteel' goats that grow spider silk proteins in their milk, transgenic fruit flies, and a Silkie chicken, bred through the continuation of a recessive gene for its fluffy, fur-like coat. Star exhibits include 'Atomic Age Rodents' and the 'PostNatural Organisms of the European Union’ (2019, unpaginated).

At the Centre for PostNatural History (n.d.) post-natural history is defined as (i) "the study of the origins, habitats, and evolution of organisms that have been intentionally and beritably altered by humans" (emphasis in original) and (ii) "the record of the influence of human culture on evolution." Post-natural, then, is about biotech, and the firm known simply as the Company is a biotech firm, as we come to realise, and had manufactured many of these lifeforms, from Mort to Borne. ${ }^{4}$ Borne, as Rachel discover towards the very end, was one of many such creations:

But the last shipment from the Company had been Borne-many Bornes. Hundreds had spilled out from the containers in front of the slow mirror. Marked as children's toys, but the diagram on the side of the containers did not match what had rolled out of the crates. Borne pods. Dormant, trapped here by whoever among the remnants had had the foresight to close off the level.

This explicitly identifies Borne as a biotech item. Besides these Bornes, other lifeforms had been created by the Company to function as weaponry. For instance, the monster fish that Wick helped build:

The purpose of his monstrous fish had been to serve as enforcer and crowd control, to instil fear, and perhaps to kill. In some remote place, a government still had had, at the time, the authority or the stability to restore order, was invested in restoring it.

The first argument that is invited by the text's theme of bioengineered life is the link between lifeforms, biotechnology and capital. The post-natural is a consequence of large-scale

\footnotetext{
${ }^{3}$ In an interesting essay, Gary Genosko speaks of the transformation of the elements in the Anthropocene:

EARTH: dust; WATER: blood; AIR: lethal fogs; FIRE: flammables. Wrapped around these elements is the planetary phylum, a great tellurian cable bunch with its own products: EARTH: electronics; WATER: liquidities like water bottled in plastic, which throws forward diagrammatic intensities in the explosion of plastic debris; AIR: gases (greenhouse); and FIRE: smouldering car tyres, slashed rain-forests and seasonal wildfires in the great northern forests... Today, condensed air is a toxic dust of frayed oil-based materials. The example of blood as a general liquid of exchange extends beyond the human to the mountain gorillas butchered for bushmeat to feed the armies and labourers engaged in 'freelance' mining operations. (2018, p. 169, emphasis in original)

${ }^{4}$ VanderMeer has created a 'Borne bestiary' to accompany the novel. See https://www.mcdbooks.com/features/borne-33bestiary
} 
bioengineering projects where all forms of life are now engineered for specific services, functions and profits. The Company, we are told, "had come to the city unbidden, when the city was already failing and had no defenses against the intruder. For a time, the Company must have seemed a savior to the city and its people."

Rachel believes the Company was always evil:

To me, the Company was the white engorged tick on the city's flank, the place that had robbed us of resources and created chaos. The place that, it was rumored, had sent its finished products out by underground tunnels to far-distant places and left us with the dregs at the holding ponds... That was the beauty of the Companyhow it won no matter what. How it had attached itself to the history of our city, even when it no longer existed here except as a husk, a ghost, or a giant, murderous bear.

Rachel's account - in a touch of irony, she uses a metaphor of a living, parasitic organismis a critique of 'lively capital', as Kaushik Sunder Rajan terms the capitalization of life and biology (2012). Creatures big and small, the land and its constituents have all become products or by-products of the Company's initiatives. In what could very well be an account of the Company and lively capital, Allison Dunlap says about Margaret Atwood's Oryx and Crake:

By controlling and commodifying the production and reproduction of both human beings and non-human animals, the capitalist scientists of Oryx and Crake diminish the possibility of human exceptionalism, reducing both non-human animals and humans to controllable commodities. $(2013,3)$

Wick, Mord, Borne and all the lifeforms are all, essentially and to greater or lesser degrees, commodities and products that have emerged from the Company's laboratories. The postnatural then is the consequence of the series of biotech experiments that the Company had embarked upon, all of which go towards transforming the landscape, as well as its living and non-living forms. Wick tells Rachel that when her parents arrived as stowaways in Company crates, their fate was decided. Wick writes in his letter to Rachel, of the history of her family:

But if you came in a supply crate, you weren't human by Company rules. Instead, you were parts, or biotech. No exceptions. Just some small mercy that someone wouldn't kill you, a young woman, and they dumped you at the holding ponds instead, to let you die out of their sight... But your parents died inside the Company building. They were killed coming out of the crates, murdered, and you had witnessed it, seen it all, and then been thrown out into a bloody wasteland at the edge of a city you did not know, that you had never seen before.

Wick's letter opens up a line of inquiry. Is it that anybody in the crate was deemed to be nonhuman? That is, even if it was a human person inside the crate, as Rachel's parents had been persons, would the Company still deal with them as biotech products? This instantiation of lively capital by the Company is a condition of the posthuman era.

Second, the creatures that the Company created have evolved into something else, just as humans seem to have devolved. In the post-apocalyptic world of VanderMeer, the human and nonhuman have all been reduced to zoe, or bare life. In that desolate landscape, humans do not have the upper hand, and the helplessness of the humans - in the face of, for instance, 
attacks by the feral children-as they struggle to survive is a vision of a post-anthropocentric world. Each one of these lifeforms is at once subject and object in the VanderMeer mythos.

Bruce Clarke has argued that 'the nonhuman is explicitly posthuman when what comes after the human involves the elimination or replacement of the human' $(2017,147)$. However, this statement or claim implies the end of the human as we know it. VanderMeer's text does not envisage the extinction of the human as much as a dethroning of the human from the centre of the earth, or the city. Admittedly, the Magician, a mysterious character about whom we discover surprisingly little even towards the end of the tale, seeks to wrest control of the city from Mort. But as the novel proceeds we discover that such an eventuality does not come to a pass.

When the Company collapses, its 'holding ponds' and biotech material is left to erode, to further contaminate whatever remains of the city. Rachel writes:

This was pollution and contamination at the source. This was where the biotech had been tossed to die or drown or be eaten by other discarded biotech, or scavenged by vultures or coyotes or people like me, who had the arrogance to think ourselves professional scavengers of living tissue.

How much of the tissue is living due to the Company's chemical and genetic intervention is never very clear. The value of life was itself controlled by the Company when it flourished. When the Company collapses, value systems shift. For instance, with the arrival of the Magician, notes Rachel, the young possessed more value.

The third instantiation of the post-natural is, of course, Borne himself. VanderMeer leaves it uncertain as to the exact nature of Borne. Borne has a gender-Rachel refers to Borne by the masculine gender-but is anatomically and physiologically a taxonomic and ontological mystery. He is first described thus:

[A] half-closed stranded sea anemone. I found him only because, beacon-like, he strobed emerald green across the purple every half minute or so... more like a hybrid of sea anemone and squid: a sleek vase with rippling colors that strayed from purple toward deep blues and sea greens. Four vertical ridges slid up the sides of its warm and pulsating skin. The texture was as smooth as waterworn stone, if a bit rubbery. It smelled of beach reeds on lazy summer afternoons and, beneath the sea salt, of passionflowers.

Wick suspects that Borne is a biotech experiment, with good reason because, as Rachel herself notes, 'one of the terrors the Company had visited on the city in the past was to test its biotech on the streets...' Trying, at first encounter to decipher what Borne is: "What isn't it? That's the first question," he said. "Then what isn't it?" (emphasis in original) Rachel names the creature Borne because she recalls what Wick had once said about a thing he had bioengineered: "He was born, but I had borne him" (emphasis in original). Rachel thinks, at one point, that Borne is a plant, and later 'upgrade[s] him from plant to animal'. So, there is in the name itself, a reference to the idea of birthing/birth, and an idea of carrying a burden.

The ontological multiplicity - a category confusion that is the hallmark of the grotesque and the monstrous - is only one aspect of the post-natural world/era in VanderMeer. I suggest, following the work of Nicole Shukin in Animal Capital that VanderMeer's shift of emphasis 
away from the Anthropos to the various ontological hybrids - including Borne-foregrounds the rendering of all life into biotechcapital. If Mord represents biotechcapital gone 'wild'-as in no longer controlled by the Company or human efforts - then, the mutant feral children, 'the ones the Magician created, dissolved into the city. Some were too damaged, and these formed their own outlaw communities', are also on the rampage (but in the early parts of the novel there are suggestions that they obey orders). Further, the symbolic and economic capital that is life, embodied in Borne and the other creatures/creations/mutations can no longer be distinguished as two forms of capital. VanderMeer's text resonates with Shukin's argument that 'the social flesh and 'species body' at stake in the logic of biopower is predominantly human" (2009, 9).

\section{Posthuman subjectivity}

In a prescient summary Rosi Braidotti writes:

Posthuman subjectivity is an ensemble composed by zoe-logical, geological and technological organisms - it is a zoe/geo/techno assemblage...The posthuman subject is then embodied and embedded, and its relational affectivity produces a shared sense of belonging to, and knowledge of, the common world we are sharing (2019, unpaginated).

Who is Borne born to and what is his 'nature'? Rachel's association with Borne appears to resemble a maternal bond. Rachel discerns in him a 'childlike delight', a perpetual curiosity that leads him to ask questions endlessly. Then one day Borne expresses his desire to move out of Rachel's apartment. Rachel records her thoughts:

Castigating myself already, cursing how I didn't know how to be a good mother. How of course if I forbid him to go outside, if I offered up slights, I might not even recognize that he'd leave me. And also: Wasn't this the natural progress of a child growing up so fast? To become an adult. To move out. To be on their own.

It is Rachel's perception, coloured by the human's evolutionary and developmental schema, that makes her see and treat Borne as a child. She admits she did not wish to see this transformation: "I hadn't wanted to admit it at first, because the idea of growth carried with it the idea of a more radical change, the thought of a child becoming an adult."

Central to the assumption of adulthood in Borne is his range of emotions (as witnessed by Rachel):

“It's okay, Rachel,” Borne said. "It's okay."

"No, it's not okay."

Borne's eyes flashed up at me, and another new thing: anger, and not over me saying no to him. This was a real thing, an adult emotion that had never been there before. It expressed itself through an orange-red glow just visible at the core of him. Who knew if red meant caution to Borne, but he knew it meant that to me.

Next is the development of an awareness (in Borne) of his vulnerability and mortality: 
He knew now that he could be harmed. He knew now that he was vulnerable. No joy would be the same for Borne. No playfulness, either. Because behind it would be this certain knowledge: that he could die.

Rachel attributing a consciousness of his vulnerability and mortality is, again, an anthropocentering of the world: the assumption that she understands whatever Borne is experiencing.

For Braidotti, the affective and relationality is 'is an alternative to individualist autonomy' (2019, unpaginated). The manner in which VanderMeer portrays Borne's emotions implies that (i) whatever Borne is, he has assimilated human emotions and (ii) is able to communicate this emotion in a way that the human, Rachel, can understand. That is, the language (here colour) of Borne's emotion builds on the human sense of these emotions. How much of this emotion is Borne's is anybody's guess? In other words, Borne's affective range, Rachel (and VanderMeer) infer, are adaptations of and for the humans to perceive and understand. This of course recenters the Anthropos as the epicentre of the world in VanderMeer's novel. If affect and self-consciousness are markers of subjectivity, then Borne's subjectivity, such as it is, is an appropriation and incorporation of the human one.

There are frequent queries from Borne whether he is a person or not. At one point, when Rachel thinks of him as a machine, Borne contradicts her: "I am not a machine. I am a person. Just like you, Rachel. Just like you." Soon after, he discusses the matter with Rachel:

“Am I a person?” Borne said, and his eyestalks perked up and took special attention.

I didn't hesitate. "Yes, Borne, you are a person."

He was a person to me, but one already pushing on past to other concepts.

"Am I a person in my right mind?"

Later Rachel thinks:

I tried to think like Borne then: A very large invertebrate only getting larger, who needed room to stretch out. With skin that was more intelligent than mine. He wasn't human, even if he was a person.

This directly resonates with the posthuman debate around whether only humans can be persons. Borne's extensive meditation in his journal also reiterates the question of his humanity_ or its absence — in considerable detail. He even tries to develop a code of conduct for himself:

BORNE MUST STOP KILLING. BORNE MUST STOP TASTING. BORNE MUST STOP BEING BORNE. BORNE MUST EAT WHAT IS ALREADY DEAD, LIKE NORMAL PERSONS.

What if I am the only one?

What if I cannot die?

What if no one made me? (emphasis in original)

This is Borne trying to approximate to the human code of conduct. 
Borne, towards the end of the novel, is a shapeshifter and can assume the form of Rachel herself. The incident shocks Rachel, and Borne is then thrown out of their dwelling.

I rounded the corner, burst through the doorway into Wick's laboratory.

I came in on Rachel talking to Wick.

I came in on myself talking to Wick.

It was a clever fake, a good likeness, and it shook me to the core, to see myself like that. To see me having a conversation with Wick as if my body had been stolen and I was just a wraith.

"Wick looked over at me, looked back at the other Rachel, flinched, with defensive beetles now raging across his arm. Apparently, he could tell the original from the mimic.

"What are you?" he was shouting at the other Rachel. "What are you?"

But I knew what the other Rachel was.

The other Rachel was Borne. (emphasis in original)

This is a pivotal moment, when Rachel recognizes that Borne can be born again and again in any form he chooses. He is Borne, he is (also) Rachel. He is animal, he is human. VanderMeer's play with ontological categories points to a post-natural world where all subjectivity is intersubjectivity, across species and beings. When, towards the end, Borne swallows Mord, he is at once Borne and Mord, neither Borne nor Mord.

VanderMeer is signalling a subjectivity where there are no borders between subjects. Biotech 'products' and 'natural' forms merge, adapt producing what I elsewhere termed a 'congeries' (Nayar, 2013, 7). Braidotti too emphasizes this condition:

Thus, I come to my first concluding proposition: the proper subject of the posthuman convergence is not 'Man', but a new collective subject, a 'we-are-(all)-inthis-together-but-we-are-not-one-and-the-same' kind of subject. This means that humanity is both a vulnerable and an insurgent category. Posthuman subjectivity can be understood as a process of becoming in its own immanence and not in binary oppositional terms (2019, unpaginated).

If, as suggested, Borne is a congeries of human, animal, biotech product, he is also perceived as a monster by Wick and on occasion by Rachel too.

Borne became an open secret that existed between us like a monster all its own...

A cheery monster, living in a hole in the ground...

Me and my lizard-monster....

As I looked up at Borne there were no constellations bright enough to blind me to him as a monster. 
Borne is a monster of the post-natural era. If, as Jeffrey Jerome Cohen characterizes the monster as marked by a 'refusal to participate in the classificatory "order of things"" (1996, 6), Borne is a monster. For Rachel, Borne's monstrosity is not that he is completely different but that he is uncannily similar to (and can mimic) the human, or become human. That is, it is the ability to be human, assuming the shape and features of the human, that is monstrous. Note what Rachel says about Mord:

The truth was, I didn't want Mord to be more like us. I wanted him to be less like us. To be able to say when he murdered, when he pillaged, that he was a psychotic beast, a creature without the possibility of redemption, with no humanity in him.

The monstrosity is even less acceptable when the creature is akin to the humans. When he demonstrates how he assimilates the human, Borne has proved that his is a free-floating subjectivity. That said, Borne, Mord and the biotech creatures are not the only monstrosities in the novel. Monstrous subjectivity is also the feature of those like Wick, and Rachel herself. Living scrounging off the land and the detritus of the Company's products, but also reliant on bioengineered lifeforms to survive, their physiologies, anatomies and subjectivities hinge on these 'others'. Sherryl Vint's reading of contemporary zombie texts signals an abject posthumanism, "in which humanity becomes split between surviving 'real' humans and infected, dangerous posthumans (the zombies; the infected), a literalization of what Foucault has termed the racism of modern biopolitical governance" $(2013,139)$. The point I wish to underscore is: although characters like Wick or the other scavenger-humans are not zombies per se, they approximate to an abject posthuman condition because they exist on the threshold of the human and the abjected, biotech-dependent creations (and/or former employees) of the Company. There are sufficient hints that Wick is himself a Company product and hence post-natural. Whether he is the monstrous fish now transformed into a human is also a moot point. Rachel records:

For in one of the rooms I had found what he had hid so ably and so well, lived with for so long: There was a mound of discarded diagrams and models for biotech. Boxes full of withered-away parts. Each one had some version of Wick's face. Crushed. Cracked. Discarded. Tossed aside. Abandoned. Discontinued.

Wick had never been a person.

But he had always been a person to me.

Personhood, VanderMeer implies, is in the eye of the beholder. Wick, Rachel discovers, may have been bioengineered, but to such an exemplary perfection that he was a person to her: with all the qualities of the human. Whether Wick then represents the perfectibility of humanity (via biotech, as those such as Nick Bostrom, favouring transhumanism and human enhancement argue) or an abject posthuman form remains unanswerable at the end of the novel. Abject posthuman subjectivity is not, then, about the zombification of the human through infection and/or contagion. It is the condition of abjection, of bare life, that 
constitutes their very being when forced to live with biotech forms and they are reduced to agency-less agents. ${ }^{5}$ This comes home to Rachel when she states:

Many [biotech creations, the Mord proxies] died within three or four years, and those left were both more dangerous and more civilized. They had their own intricate chirping, huffing language and have begun to develop their own customs. The cubs are far removed already from unthinking violence and act more like bears: wary and clever and more cautious, as if they understand better their place.

All nature in the city, she says, will be post-natural. This seems to indicate a future of monsters. Writing about Anthropocene monsters in VanderMeer's Southern Reach trilogy, Gry Ulstein argues that such a monster induces fear because the monstrous will cause the humans 'to be colonized, assimilated, altered, and forcefully evolved' (2017, 92). Arguing via Timothy Morton's view of hyperobjects, Ulstein writes:

Anthropocene monsters display their complete indifference to humanity's qualms and cares, and nobody knows quite how to tame them-let alone squeeze their massive bodies into a human frame of reference. $(2017,93)$

VanderMeer leaves us in no doubt that abject posthumanism is very much on the cards with the rise in influence and impact of biotechnology. The post-natural is the future history of the human race, and of all lifeforms.

\section{References}

Braidotti, R. (2019). Posthuman knowledge. Polity. eBook.

Clarke, B. (2017). The nonhuman. In B. Clarke \& M. Rossini (Eds.) The Cambridge Companion to Literature and the Posthuman (pp. 141-152). Cambridge University Press.

Cohen, J.J. (1996). Monster Culture (Seven Theses). In J.J. Cohen (Ed) Monster Theory: Reading Culture (pp. 3-25). University of Minnesota Press.

Dunlap, A. (2013). Eco-dystopia: Reproduction and destruction in Margaret Atwood's Oryx and Crake. Journal of Ecocriticism, 5(1), 1-15.

Genosko, G. (2018). Four elements. In R. Braidotti \& M. Hlavajova (Eds.) Posthuman Glossary (pp. 167169). London: Bloomsbury.

Nayar, P. K. (2013). Posthumanism. Polity.

PostNatural History. (n.d.). About. Center for PostNatural History. https://www.postnatural.org/ About

Rajan, K. S. (2012). Lively capital: Biotechnology, ethics, and governance in global markets. Duke University Press. Shukin, N. (2009). Animal capital: Rendering life in biopolitical times. University of Minnesota Press.

Ulstein, G. (2017). Brave new weird: Anthropocene monsters in Jeff VanderMeer's The Southern Reach. Concentric, 43(1), 71-96.

Vint, S. (2013). Abject posthumanism: Neoliberalism, biopolitics, and zombies. In M. Levina \& D. M. T. Bui (Eds.) Monster culture in the 21 ${ }^{\text {st }}$ Century (pp. 133-146). Bloomsbury.

VanderMeer, Jeff. (2017). Borne. MCD-Farrar, Straus and Giroux.

Wyatt, C. (2017, May 25). Interview: Jeff VanderMeer on "Borne". Weird Fiction Review. https://weirdfictionreview.com/2017/05/interview-jeff-vandermeer-borne/. Accessed 13 Dec. 2020.

\footnotetext{
${ }^{5}$ In an interview VanderMeer says:

Borne may be created biotech, with the "nature" part reinforced by his "made" existence. The significance of nature versus nurture is thus a very different thing for Borne than for Rachel or Wick, where they may have more ability to reinvent themselves ... even as in the background all kinds of other things are reinventing themselves as well. (Wyatt 2017).
} 